\title{
DETERMINATION OF ELASTIC PROPERTIES OF CEMENT-SAND COMPOSITION USING STRUCTURAL SIMULATION MODELING
}

\author{
Yuri E. Kurbatov, Galina G. Kashevarova \\ Perm National Research Polytechnic University, Perm, RUSSIA
}

\begin{abstract}
The estimation of quantitative influence of fine-grained concrete structural elements on its strength characteristics is a very actual task requiring application of computer technologies. In this article, the authors propose a structural and simulation model of cement-sand composition, which includes pores, cement stone, sand and the contact zone between them. As a result of the numerical calculation of this model, the integrated elastic characteristics of the material (modulus of elasticity and Poisson's ratio) are obtained, which can be assigned as initial data for the model of a higher scale level in order to optimize the composition of concrete.
\end{abstract}

Keywords: cement-sand composition, fine-grained concrete, structural simulation modeling, mesostructure, Monte Carlo method, boundary problem, contact zone

\section{ОПРЕДЕЛЕНИЕ УПРУГИХ ХАРАКТЕРИСТИК ЦЕМЕНТНО-ПЕСЧАНОЙ КОМПОЗИЦИИ МЕТОДОМ СТРУКТУРНО-ИМИТАЦИОННОГО МОДЕЛИРОВАНИЯ}

\author{
Ю.Е. Курбатов, Г.Г. Кашеварова
}

Пермский национальный исследовательский политехнический университет, г. Пермь, РОССИЯ

\begin{abstract}
Аннотация: Оценка количественного влияния структурных элементов мелкозернистого бетона на его прочностные характеристики является весьма актуальной задачей, требующей применения компьютерных технологий. В данной статье авторами предложена структурно-имитационная модель цементно-песчаной композиции, включающая в себя поры, цементный камень, песок и контактную зону между ними. В результате численного расчета данной модели получены интегральные упругие характеристики материала (модуль упругости и коэффициент Пуассона), которые могут быть назначены в качестве исходных данных для модели более высокого масштабного уровня с целью оптимизации состава бетона.
\end{abstract}

Ключевые слова: цементно-песчаная композиция, мелкозернистый бетон, структурно-имитационное моделирование, мезоструктура, метод Монте-Карло, краевая задача, контактная зона

\section{INTRODUCTION}

Structural-simulation modeling (SSM) is one of the most effective tools which is suitable for the description of the complex structured systems such as fine-grained concrete. SSM allows to take into account the distribution of structure components in space, their mutual orientation and pairing. In [1] the author presents an analytical review of existing approaches to SSM of a complex composite structures such as fibrobeton, analyzes the main stages of modeling, including the creation of geometry and orientation of structural elements in space, the appointment of effective properties, binding and loading the model.

In the paper [2] Haritonov A.M. offers a generalizing model of fine-grained concrete structure, which can be used to study the heterogeneity of stress distribution in the 
material volume. This phenomenon, according to the author, can be explained by a large difference in the values of the elastic modulus of cement stone and fine aggregate. The author created a flat model of cement-sand composite microstructure on three scale levels in order to calculate it. At the same time, the author's program "PoreSolution" [3], implementing the Monte Carlo method, was used to place the structural elements of the model within a given area. An experiment on static compression of a flat concrete model for developed geometrical and finite element models was simulated (see Figure1). Boundary conditions of the experiment are shown in Figure 2. Performed in the work [2] studies have allowed to obtain the strength and deformation regularities in the behavior of cement-sand compositions depending on their composition.

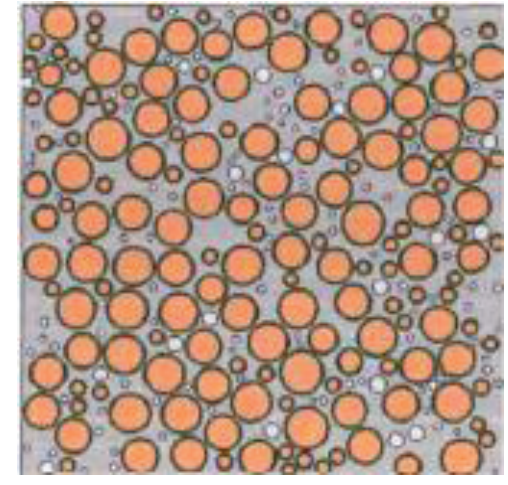

a

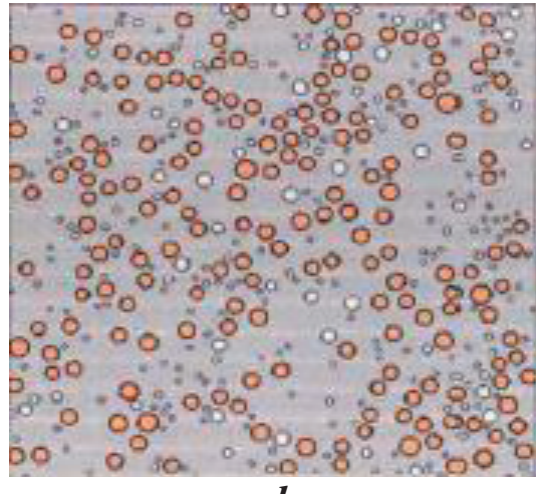

b

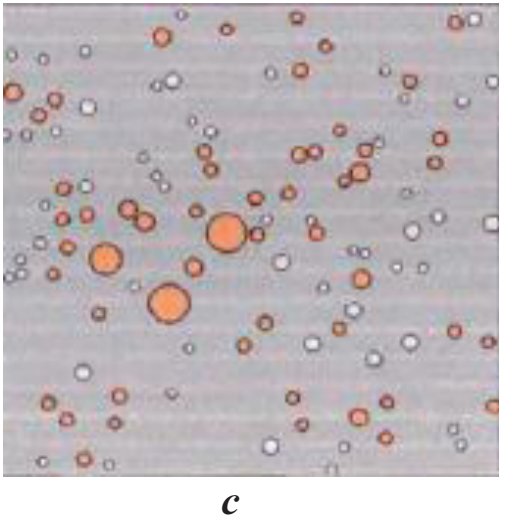

c

Figure 1. The geometric model of cement-sand compositions structure [2]:

a) $5 \times 5 \mathrm{~mm}$; b) $20 \times 20 \mathrm{~mm}$; c) $50 \times 50 \mathrm{~mm}$.

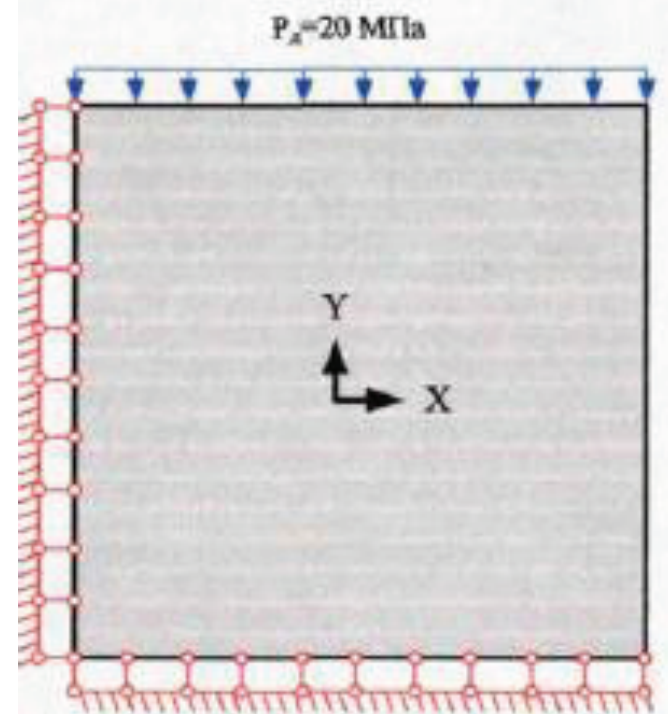

Figure 2. Boundary conditions of the calculation scheme [2].

The authors of this publication have set an aim to conduct an own independent computational experiment on the basis of the study described above to determine additional output parameters and to conduct a comparative analysis of the results with the data presented in [2]. At the same time, to form the geometric scheme of the cement-sand composition, an alternative program in the APDL language was written. Thus, all stages of the computational experiment were implemented in one software environment - ANSYS Mechanical. 


\section{CONDUCTING OF THE COMPUTATIONAL EXPERIMENT}

The formulation of the boundary value problem in this case is traditional for the structuralsimulation approach. The basic relations of the elasticity theory are given below:

$$
\begin{gathered}
\sigma_{i j, j}(r)+F_{i}(r)=0 \\
\varepsilon_{i j}(r)=\frac{1}{2}\left(U_{i, j}(r)+U_{j, i}(r)\right) \\
\sigma_{i j}(r)=C_{i j k l}(r)\left(I_{i j k l}-\Pi_{\mathrm{ijk} 1}(r)\right) \varepsilon_{k l}(r) \\
\sigma_{i j} \times n_{j}=F_{i} \\
\left.u\right|_{\Gamma}=u^{*}
\end{gathered}
$$

The concept of "probabilistic-geometric concentration" proposed in [4] was used to create a structural-simulation model. A distribution of pores and grains of sand by size, porosity and arrangement of pores and solid phases in model space were considered as a major probability factors that define the geometry model. The design plane of the model is taken in the form of a square with dimensions of 50 x $50 \mathrm{~mm}$. Structural components which considered in the model are as follows:

- the matrix (cement stone);

- grains of sand (0,5-1 mm);

- pores (sizes range from $0.2 \mathrm{~mm}$ to $0.8 \mathrm{~mm}$ );

- the contact area between the grains of the filler and the matrix (thickness $0.2 \mathrm{~mm}$ ).

The form of pores and grains of sand is conditionally accepted as circles for simplification of construction of a finite-element grid. The contact area is simulated as an annular shell around each grain of sand.

The modulus of elasticity (E) and Poisson's ratio $(\mu)$ of quartz sand are adopted on the basis of literature data and are equal to: $\mathrm{E}=72,8 \mathrm{GPa}$, $\mu=0,167$. The values of the modulus of elasticity and Poisson's ratio of the contact zone are assumed to be equal 10,6 GPa и 0,30 (according to estimates obtained in the work [5]).
The above values were recalculated for use in two-dimensional formulation [6] in order to prepare for the calculation:

$$
\begin{gathered}
E_{2}=\frac{E_{3}}{\left(1-\mu_{3}^{2}\right)}, \\
\mu_{2}=\frac{\mu_{3}}{\left(1-\mu_{3}\right)},
\end{gathered}
$$

The values of modulus of elasticity and Poisson's ratio of cement stone for each calculated composition (P1...P10, see Table 2) are taken from the results of experiments carried out at the previous scale level $(20 \times 20 \mathrm{~mm})$ in [2]. These values are assigned as initial values for cement stone in model 50x50 mm. Figure 3 shows a typical geometric scheme of the composition for P1, built by the author's macroprogram in the language APDL (ANSYS Mechanical). Each time you run the program, it implements a new packaging option that does not repeat the previously built layouts. The conditions of fastening and loading were taken in accordance with Figure 2.

The following two types of finite elements have been selected to build the mesh in the ANSYS library: PLANE 182 and PLANE 183. According to the results of preliminary calculations on two corresponding meshes (with the same partition step, but with different types of finite elements) in one case, the result was noticeably overestimated relative to the experimental value, in the other - slightly understated (see Table 1). After the final selection of the finite element type (PLANE183), a second preliminary calculation was carried out, also on two finite element meshes, but with a different partition step $(0.2$ $\mathrm{mm}$ and $0.4 \mathrm{~mm}$ ). Based on the results shown in Table 2, it can be concluded that the $0.2 \mathrm{~mm}$ mesh pitch gives a slightly more accurate result. The enlarged fragment of this mesh is shown in Figure 4. 


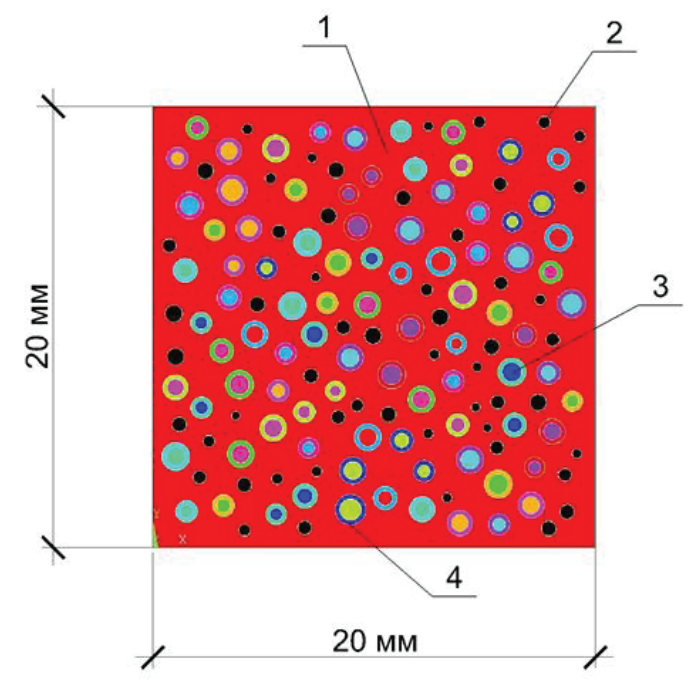

Figure 3. Geometry of composite for structure P1

1 - cement matrix 2 -pore 3 -sand particle 4 -contact area.

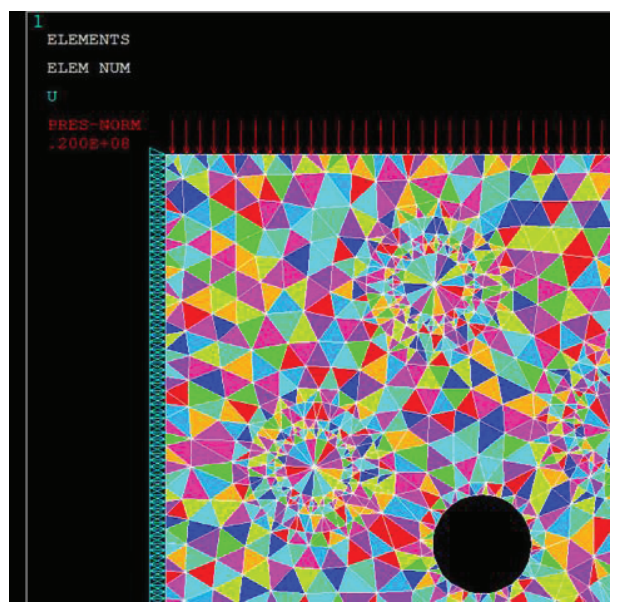

Figure 4. The enlarged fragment of the calculation scheme for the composition PI

Table 1. Parameters of material.

\begin{tabular}{|c|c|c|c|c|c|c|c|}
\hline \multirow{3}{*}{ Composition } & \multirow{3}{*}{$\begin{array}{c}\text { Sand } \\
\%\end{array}$} & \multirow{3}{*}{$\begin{array}{c}\text { Pores } \\
\%\end{array}$} & \multicolumn{5}{|c|}{ Modulus of elasticity, GPa } \\
\hline & & & \multirow{2}{*}{$\frac{E_{\text {эксп }}{ }^{*}}{\text { 3D }}$} & \multicolumn{2}{|c|}{$E_{\text {pacu }}$ (PLANE 182) } & \multicolumn{2}{|c|}{$E_{\text {расч }}($ PLANE 183) } \\
\hline & & & & 2D & 3D & 2D & 3D \\
\hline $\mathrm{P} 1$ & 47,4 & 19,86 & 22,41 & 25,262 & 23,843 & 23,068 & 21,772 \\
\hline
\end{tabular}

Table 2. Parameters of material.

\begin{tabular}{|c|c|c|c|c|c|c|c|}
\hline \multirow{3}{*}{ Composition } & \multirow{3}{*}{$\begin{array}{c}\text { Sand } \\
\%\end{array}$} & \multirow{3}{*}{$\begin{array}{c}\text { Pores } \\
\%\end{array}$} & \multicolumn{5}{|c|}{ Modulus of elasticity, GPa } \\
\hline & & & \multirow{2}{*}{$\frac{E_{\text {эरс⿰丿丶 }}{ }^{*}}{\text { 3D }}$} & \multicolumn{2}{|c|}{$E_{\text {pacu }}(\mathrm{s}=0,4 \mathrm{~mm})$} & \multicolumn{2}{|c|}{$E_{p a c u}(\mathrm{~s}=0,2 \mathrm{~mm})$} \\
\hline & & & & 2D & 3D & 2D & 3D \\
\hline $\mathrm{P} 1$ & 47,4 & 19,86 & 22,41 & 23,020 & 21,727 & 23,068 & 21,772 \\
\hline
\end{tabular}


In preparation for the main series of strength calculations for each composition (P1...P10) it was formed on three models with different distribution of structural components in the plane of the model, but with the same percentage, with one type of finite element (PLANE 183), and with one partition step (0.2 $\mathrm{mm})$. The results were averaged for each composition. Then the summary Tables 3 and 4 were made, in which the values of the modulus of elasticity and Poisson's coefficients specified in [2] $\left(\boldsymbol{E}_{\text {эксп }}{ }^{*}, \boldsymbol{E}_{\text {теор }}{ }^{*}, \boldsymbol{\mu}_{\text {теор }}{ }^{*}\right)$, and received as a result of the executed calculations $\left(E_{\text {расч }}, E_{\text {инт }}, E_{\text {экв }}, \mu_{\text {расч }}\right)$.

Table 3. Parameters of material.

\begin{tabular}{|c|c|c|c|c|c|c|c|c|c|c|}
\hline \multirow{3}{*}{$\begin{array}{c}\text { Compo } \\
\text { sition }\end{array}$} & \multirow{3}{*}{$\begin{array}{c}\text { Sand } \\
\%\end{array}$} & \multirow{3}{*}{$\begin{array}{c}\text { Pores } \\
\%\end{array}$} & \multicolumn{8}{|c|}{ Modulus of elasticity, GPa } \\
\hline & & & \multirow{2}{*}{$\begin{array}{c}E_{\text {эксп }}^{*} \\
\mathbf{3 D}\end{array}$} & \multicolumn{2}{|c|}{$E_{\text {mеop }}^{*}$} & \multicolumn{2}{|c|}{$E_{p a c u}$} & \multirow{2}{*}{$\begin{array}{c}E_{\text {инт }} \\
\text { 2D }\end{array}$} & \multirow{2}{*}{$\begin{array}{c}E_{\text {экв }} \\
\text { 2D }\end{array}$} & \multirow{2}{*}{$\frac{E_{\text {экв }}}{E_{\text {расч }}}$} \\
\hline & & & & $2 D$ & 3D & 2D & 3D & & & \\
\hline $\mathrm{P} 1$ & 47,4 & 19,86 & 22,41 & 25,7 & 24,3 & 22,884 & 21,599 & 26,097 & 42,358 & 1,85 \\
\hline $\mathrm{P} 2$ & 48,9 & 19,09 & 23,95 & 26,8 & 24,4 & 23,484 & 22,165 & 26,214 & 43,241 & 1,84 \\
\hline P3 & 52,3 & 17,68 & 32,01 & 33,3 & 31,5 & 28,187 & 26,604 & 32,015 & 46,475 & 1,65 \\
\hline $\mathrm{P} 4$ & 49,1 & 18,13 & 25,34 & 27,0 & 25,6 & 23,560 & 22,237 & 28,752 & 43,844 & 1,86 \\
\hline $\mathrm{P} 5$ & 53,2 & 20,25 & 22,03 & 25,1 & 23,8 & 21,932 & 20,762 & 27,379 & 44,834 & 2,04 \\
\hline P6 & 55,3 & 17,65 & 27,81 & 29,3 & 27,8 & 24,667 & 23,351 & 30,037 & 47,107 & 1,91 \\
\hline P7 & 56,1 & 17,21 & 30,56 & 32,2 & 30,5 & 27,701 & 26,223 & 31,439 & 47,875 & 1,73 \\
\hline P8 & 55,4 & 19,62 & 20,60 & 23,4 & 22,2 & 21,383 & 20,242 & 28,142 & 45,921 & 2,15 \\
\hline P9 & 58,3 & 20,05 & 22,44 & 25,9 & 24,6 & 21,091 & 20,023 & 30,808 & 47,337 & 2,24 \\
\hline P10 & 66,1 & 18,70 & 19,02 & 22,8 & 21,4 & 19,492 & 18,504 & 25,998 & 50,766 & 2,60 \\
\hline
\end{tabular}

Table 4. Parameters of material.

\begin{tabular}{|c|c|c|c|c|c|c|}
\hline Composition & Share of sand, \% & \multirow{2}{*}{ Porosity, \% } & \multicolumn{4}{|c|}{ Poisson's ratio } \\
\cline { 5 - 7 } & & & \multicolumn{2}{|c|}{$\mu_{\text {meop }}^{*}$} & \multicolumn{2}{|c|}{$\mu_{\text {pacu }}$} \\
\cline { 5 - 7 } & & 19,86 & 0,31 & $\mathbf{0 , 2 4}$ & 0,310 & $\mathbf{0 , 2 3 7}$ \\
\hline P1 & 47,4 & 19,09 & 0,31 & $\mathbf{0 , 2 4}$ & 0,310 & $\mathbf{0 , 2 3 7}$ \\
\hline P2 & 48,9 & 17,68 & 0,30 & $\mathbf{0 , 2 3}$ & 0,310 & $\mathbf{0 , 2 3 7}$ \\
\hline P3 & 52,3 & 18,13 & 0,30 & $\mathbf{0 , 2 3}$ & 0,310 & $\mathbf{0 , 2 3 7}$ \\
\hline P4 & 49,1 & 20,25 & 0,30 & $\mathbf{0 , 2 3}$ & 0,300 & $\mathbf{0 , 2 3 1}$ \\
\hline P5 & 53,2 & 17,65 & 0,30 & $\mathbf{0 , 2 3}$ & 0,300 & $\mathbf{0 , 2 3 1}$ \\
\hline P6 & 55,3 & 17,21 & 0,30 & $\mathbf{0 , 2 3}$ & 0,301 & $\mathbf{0 , 2 3 1}$ \\
\hline P7 & 56,1 & 19,62 & 0,30 & $\mathbf{0 , 2 3}$ & 0,300 & $\mathbf{0 , 2 3 1}$ \\
\hline P8 & 55,4 & 20,05 & 0,29 & $\mathbf{0 , 2 2}$ & 0,291 & $\mathbf{0 , 2 2 5}$ \\
\hline P9 & 58,3 & 18,70 & 0,29 & $\mathbf{0 , 2 2}$ & 0,291 & $\mathbf{0 , 2 2 5}$ \\
\hline P10 & 66,1 & & & & 2D \\
\hline
\end{tabular}

\section{RESULTS OF CALCULATION}

Several approaches were used to obtain the values of the modulus of elasticity and Poisson's ratio based on the results of the computational experiment. According to [7], modulus of elasticity $E_{p a c u}$ is defined as the ratio of voltage increment from zero to the level of external load equal to $30 \%$ from the damage (20 $\mathrm{MPa}$ according [2]), to the increment of elasticinstantaneous relative deformation of the sample. The Poisson ratio is calculated as the ratio of the elastic-instantaneous relative transverse strain to the longitudinal strain of the specimen. Thus devices for measurement of 
deformations of a concrete sample in the form of a cube shall be established on four free sides. In accordance with the indication (in the transition to the plane problem), the results of strength calculation in ANSYS (values of the elastic deformations) was determined in the nodes located on the free right edge of the model (see Figure 2). According to the obtained data, the average values of longitudinal and transverse strain on the face were calculated (see tables 3 and 4). The calculated values of the elastic modulus $E_{\text {pacu }}$ and Poisson's ratio $\mu_{\text {pacu }}$ were determined. Figure 5 shows the distribution fields of elastic longitudinal deformation for the composition P3, which provided the highest value among all the simulated compositions.

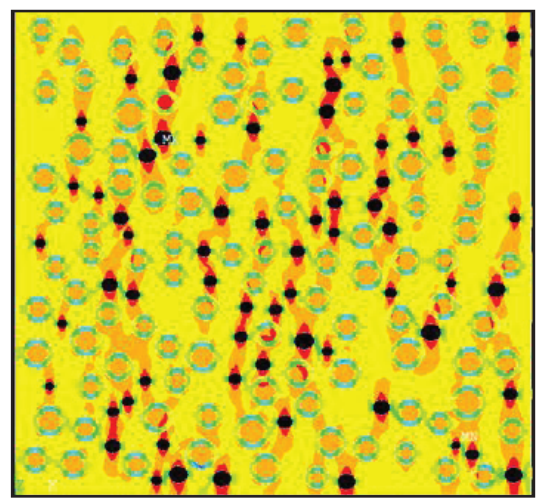

Figure 5. Elastic longitudinal deformation of the composite composition P3.

The second approach to the calculation of the elastic modulus is based on the calculation of the integral value of the obtained data on the stressstrain state in each node of the model. The value of the elastic modulus was defined as the ratio of the normal stress in the node to the elastic longitudinal deformation in the same node:

$$
E_{\text {uнmi }}=\frac{\sigma_{y i}}{\varepsilon_{y i}} .
$$

Then the integral modulus of elasticity was determined as the average value for all nodes:

$$
E_{\text {uнт }}=\sum E_{\text {uнті }} .
$$

The equivalent modulus of elasticity takes into account the degree of influence of the structure components on the elastic properties of the composite and is calculated by the following expression:

$$
\sigma_{\text {экв }}=\sum_{m=1}^{N}\left(k_{m} E_{m}\right)
$$

This value sums the shares of the "contribution" of individual phases to the strength of the model in proportion to the volume occupied by them in the structure of the model. It is obvious that the equivalent modulus of elasticity differs markedly from the actual absolute value of the resulting young modulus. In the paper [2] the following relation is obtained, which according to the author is almost constant:

$$
E_{\text {экв }}^{*}=1,61 E_{\text {теор }}^{*}
$$

However, according to the results of calculations shown in table 5, the authors of this article found that the ratio is variable and varies in the range of $1.65 \ldots 2,60$. Thus, three alternative values of the elastic modulus for each composition were obtained by different methods, which were compared with the experimental values given in [2] $E_{\text {эксп }}^{*}$ and numerical values $E_{\text {meop }}^{*}$, received on results of calculations. A comparison of the values of all the above values is given in Table 5 . 
Table 5. Comparison of results.

\begin{tabular}{|c|r|r|r|r|}
\hline \multirow{3}{*}{ Composition } & \multicolumn{4}{|c|}{ Difference (in \%) between: } \\
\cline { 2 - 5 } & \multicolumn{2}{|c|}{$E_{\text {расч }}$ И... } & $\begin{array}{c}E_{\text {инт }} \\
\text { и ... }\end{array}$ & $\frac{E_{\text {экв }}}{E_{\text {расч }}}$ \\
\cline { 2 - 5 } & $E_{\text {эксп }}^{*}$ & $E_{\text {теор }}^{*}$ & $E_{\text {теор }}^{*}$ & $\frac{E_{\text {экв }}^{*}}{E_{\text {теор }}^{*}}=\mathbf{1 , 6 1}$ \\
\hline P1 & 3,62 & 11,12 & 1,52 & 12,97 \\
\hline P2 & 7,45 & 9,16 & 2,19 & 12,50 \\
\hline P3 & 16,89 & 15,54 & 1,61 & 2,42 \\
\hline P4 & 12,25 & 13,14 & 6,09 & 13,44 \\
\hline P5 & 5,76 & 12,76 & 8,32 & 21,08 \\
\hline P6 & 16,03 & 16,00 & 2,45 & 15,71 \\
\hline P7 & 14,19 & 14,02 & 2,36 & 6,94 \\
\hline P8 & 1,74 & 8,82 & 16,85 & 25,12 \\
\hline P9 & 10,77 & 18,61 & 15,93 & 28,13 \\
\hline P10 & 2,71 & 13,53 & 12,30 & 38,08 \\
\hline
\end{tabular}

\section{CONCLUSION}

The obtained results of the mechanical properties calculations allow us to conclude that a consistent increase in the percentage of sand in the composition to $50-55 \%$ leads to an increase in the value of the elastic modulus, but with a further increase in the reinforcement of the cement stone with a small filler, there is a significant decrease in the elastic characteristics of the material.

The obtained values can be used to assign the physical properties of the matrix of a higher scale level (for example, in coarse-grained concrete). Thus, the developed structural simulation model of cement-sand composition allows reproducing the most important mechanical characteristics of the material in order to assess the impact of individual structural components on the strength of the composite.

\section{REFERENCES}

1. Kurbatov Y.E. Problemy i Vozmozhnye Napravlenija Reshenija Zadachi StrukturnoImitacionnogo

Modelirovanija
Fibrobetonnogo Kompozita [Problems and Possible Directions of Solving Problems of Structural-Simulation Modeling of Fiber Composites]. // Vestnik Perm National Research Polytechnic University. Applied ecology. Urbanistics, 2017, No. 1, pp. 126139.

2. Haritonov A.M. Strukturno-Imitacionnoe Modelirovanie v Issledovanijah Svojstv Cementnyh Kompozitov [Structuralsimulation Modelling to Study the Properties of Cement Composites]. Dr.Sc. Thesis, Saint Petersburg, 2009, 365 pages.

3. Haritonov A.M. Modelirovanie Struktury Cementnogo Kamnja i Processov Usadki "PoreSolution v2.0" [Modeling of Cement Stone Structure and Processes of Shrinkage "Pore Solution v2.0". Certificate of official registration program for computer No. 2008614295 from 08.09.2008.

4. Bazhenov Y.M., Vorob'ev V.A., Ilyukhin A.V. Komp'juternoe Materialovedenie i Novyj Algoritm Modelirovanija Struktury Stroitel'nyh Kompozicionnyh Materialov [Computer Science a New Algorithm for Modeling the Structure of Composite Materials. // Design and Execution - 
Guarantors of Safety of Life: Proceedings of General Meeting of RAACN (two volumes). Saint-Petersburg State University of Architecture and Civil Engineering, 2006, Volume 1, pp. 142-148.

5. Haecker, G.-J., Garboczi E.J., Bullard J.W., Bohn R.B., Sun Z., Shah S.P., Voigt T. Modeling the Linear Elastic Properties of Portland Cement Paste. // Cement and Concrete Research, 2005, Vol. 35, No. 10, pp. 1948-1960.

6. Meille S., Garboczi E.J. Linear Elastic Properties of 2-D and 3-D Models of Porous Materials Made from Elongated Objects. // Mod. Sim. Mater. Sci. and Eng., 2001, No. 9(5), pp. 371-390.

7. GOST 24452-80. Betony. Metody Opredelenija Prizmennoj Prochnosti, Modulja Uprugosti i Kojefficienta Puassona [Concretes. Methods of Determination of Prismatic Strength, Modulus of Elasticity and Poisson's Ratio]. Moscow, STANDARTINFORM, 2005, 14 pages.

\section{СПИСОК ЛИТЕРАТУРЫ}

1. Курбатов Ю.Е. Проблемы и возможные направления решения задачи структурно-имитационного

моделирования фибробетонного композита. // Вестник Пермского национального исследовательского политехнического университета. Прикладная экология. Урбанистика, 2017, №1, с. 126-139.

2. Харитонов А.М. Структурноимитационное моделирование в исследованиях свойств цементных композитов. Диссертация на соискание ученой степени доктора технических наук по специальности 05.23.05 «Строительные материалы и изделия». СПб., 2009. - 365 с.

3. Харитонов А.М. Моделирование структуры цементного камня и процессов усадки «PoreSolution v2.0». Свидетельство об официальной регистрации программы для ЭВМ №2008614295 от 08.09.2008.

4. Баженов Ю.М., Воробьев В.А., Илюхин А.В. Компьютерное материаловедение и новый алгоритм моделирования структуры строительных композиционных материалов. // Проект и реализация - гаранты безопасности жизнедеятельности: Труды Общего собрания Российской академии архитектуры и строительных наук (в 2 томах). - СПб.: Санкт-Петербургский государственный архитектурностроительный университет, 2006, том 1, c. $142-148$.

5. Haecker, G.-J., Garboczi E.J., Bullard J.W., Bohn R.B., Sun Z., Shah S.P., Voigt T. Modeling the Linear Elastic Properties of Portland Cement Paste. // Cement and Concrete Research, 2005, Vol. 35, No. 10, pp. 1948-1960.

6. Meille S., Garboczi E.J. Linear Elastic Properties of 2-D and 3-D Models of Porous Materials Made from Elongated Objects. // Mod. Sim. Mater. Sci. and Eng., 2001, No. 9(5), pp. 371-390.

7. ГОСТ 24452-80. Бетоны. Методы определения призменной прочности, модуля упругости и коэффициента Пуассона. - М.: Стандартинформ, 2005. $-14 \mathrm{c}$.

Yuri E. Kurbatov, Ph.D. Student, Senior Lecturer, Engineer, Department "Building constructions and computational mechanics", Perm National Research Polytechnic University, 109, Kujbysheva street, Perm, 614010, Russia; phone +7 (342) 219-83-89,

E-mail: YEK-STF@yandex.ru.

Galina G. Kashevarova, Corresponding Member of Russian Academy of Architecture and Construction Sciences, Professor, Dr.Sc., Head of department "Building constructions and computational mechanics", Perm National Research Polytechnic University; Russia, 614010, Perm, ul. Kuibyshev, 109; phone +7 (342) 219-83-61, e-mail: ggkash@mail.ru. 
Determination of Elastic Properties of Cement-Sand Composition Using Structural Simulation Modeling

Курбатов Юрий Евгеньевич, аспирант, старший преподаватель кафедры «Строительные конструкции и вычислительная механика» Пермского национального исследовательского политехнического университета; 614010, Россия, г. Пермь, ул. Куйбышева, дом 109, тел. +7(342) 2198389 ,

E-mail: YEK-STF@yandex.ru.

Кашеварова Галина Геннадьевна, член-корреспондент PAАСН, доктор технических наук, профессор, заведующая кафедрой «Строительные конструкции и вычислительная механика» Пермского национального исследовательского политехнического университета; Россия, 614010, г. Пермь, ул. Куйбышева, 109, тел. +7(342) 2198379, e-mail: ggkash@mail.ru. 